\title{
THE IMPACT OF NATIONAL RURAL NETWORK'S INITIATIVES ON SOCIO-ECONOMIC DEVELOPMENT OF PODLASKIE VOIVODESHIP IN POLAND
}

\begin{abstract}
Dorota RYSZKOWSKA, Department of Spatial Management and Tourism, Faculty of Earth Sciences Nicolaus Copernicus University, Lwowska str. 1, Torun, Poland; dkozlowska@umk.pl

Czesław ADAMIAK, Department of Spatial Management and Tourism, Faculty of Earth Sciences Nicolaus Copernicus University, Lwowska str. 1, Torun, Poland; czeslaw.adamiak@umk.pl (corresponding author)

Barbara SZYDA, Department of Spatial Management and Tourism, Faculty of Earth Sciences Nicolaus Copernicus University, Lwowska str. 1, Torun, Poland; bszyda@umk.pl

National Rural Network is an important instrument for rural development in Poland. NRN is an instrument of the Rural Areas Development Programme. The main objective of NRN is to support the rural areas of the European Union by providing information, experiences and good practices for sustainable rural development. These measures are intended to improve the quality of life of rural residents and the conditions of their work. The aim of the paper is to demonstrate whether the implementation of NRN initiatives contributes to socio-economic development of rural areas in Podlaskie Voivodship. In order to achieve this objective, the projects supported by NRN for the years 2010-2017 were reviewed, and the numbers of the projects in individual poviats were compared to the changes in values of socio-economic development indicators derived from the Central Statistical Office data.
\end{abstract}

Keywords: EU funds, National Rural Network, Podlaskie Voivodeship, rural development.

\section{NATIONAL RURAL NETWORK (NRN)}

There are two keys for the development of rural areas. On one hand, top-down interventions of programmes and decisions undertaken on the national and EU level. On the other hand, crucially important is the involvement and cooperation on the local level. In this respect, important role is attributed to local self-government, and also to social organisations (foundations, associations, Local Action Groups) and local leaders. The place where EU, national, regional and local policies of support for rural development meet, is the National Rural Network (NRN).

The NRN, established in Poland in 2008, is a part of the European Network for Rural Development (ENRD), which coordinates bilateral international cooperation between rural networks of member states. The legal basis for the emergence of both European and national rural networks is Council Regulation (EC) 1698/05 of 20 September 2005 on rural support by the European Agricultural Fund for Rural Development (EAFRD) (Onofrei et al., 2009; Co to jest KSOW?, 2009; Król, 2010; Ocena funkcjonowania..., 2011; Kutkowska and Pilawka, 2014; Marquardt and Hubbard, 2014; Czapiewska, 2015).

The basic objective of establishing NRN and its regional secretaries in individual voivodships is to ensure efficient and dynamic development of rural areas by exchanging information (specialists knowledge and know-how) and disseminating knowledge in the areas of programs, to improve the effectiveness of implementation of development instruments and to equalize the opportunities and promote territorial cohesion of rural areas (Onofrei et al., 2009; Co to jest KSOW?, 2009; Drygas, 2010; Petres and Gregory, 2014; Miś, 2015). The National Rural Network should therefore serve as an instrument for exchanging best practices and supporting rural development initiatives in many dimensions and in different spatial scales.

The Regional Secretary of NRN in Podlaskie Voivodeship is considered to be relatively active. The results of research conducted by Król (2010) place it in the 6th place among 16 regional units. Podlaskie NRN has a relatively small number of partners (31 institutions). The majority of them are social organizations (42\%), local authorities (13\%), as well as secondary and higher education institutions (19\%).

The aim of the paper is to demonstrate whether the implementation of NRN initiatives contributes to socioeconomic development of rural areas in Podlaskie Voivodship. In order to achieve this objective, first the projects supported by Podlaskie Regional Secretary of National Rural Network for the years 2010-2017 were described in terms of their types, geographic location and change of their number in time. The data about the projects was derived from the

Copyright (C) 2017 The Authors. Published by Aleksandras Stulginskis University. This is an open-access article distributed under the terms of the Creative Commons Attribution License (CC-BY 4.0), which permits unrestricted use, distribution, and reproduction in any medium, provided the original author and source are credited. 
official webpage of NRN, archival information and yearly reports of activity of this institution. Then, the numbers of the projects in individual poviats (counties) were compared to the changes in values of socio-economic development indicators derived from the Central Statistical Office data, and correlation between these variables was calculated. Finally, several concrete projects and events supported by NRN were described in detail as case studies with emphasis put on the importance these projects for local development of rural areas.

\section{NATIONAL RURAL NETWORK ACTIVITIES IN PODLASKIE VOIVODESHIP}

During the period in the analysis, since 2010 till October 2017, Podlaskie Regional Secretary of NRN organised 362 events of various character. The most common were informational meetings, seminars, workshops and conferences (163 events). Other types of events included study visits, contests, stalls and fairs and festivals (Table 1). In total, the majority of events organised by Podlaskie Regional Secretary of NRN were located in Podlaskie Voivodeship (80.1\%). Further $12.7 \%$ were organised in other voivodeships of Poland, and the smallest part of the events (7.2\%) took place abroad.

Table 1. Number of events organised by Podlaskie NRN in 2010-2017 by type and location

\begin{tabular}{|c|c|c|c|c|c|}
\hline Indicator & $\begin{array}{l}\text { Total number } \\
\text { of events }\end{array}$ & $\begin{array}{l}\text { Share in } \\
\text { all events }\end{array}$ & $\begin{array}{c}\text { Number of events } \\
\text { organised in } \\
\text { Podlaskie }\end{array}$ & $\begin{array}{l}\text { Number of events } \\
\text { organised in other } \\
\text { voivodeships of } \\
\text { Poland }\end{array}$ & $\begin{array}{l}\text { Number of } \\
\text { events } \\
\text { organised } \\
\text { abroad }\end{array}$ \\
\hline All events & 362 & $100.0 \%$ & 290 & 46 & 26 \\
\hline $\begin{array}{l}\text { Informational meetings, seminars, } \\
\text { workshops and conferences }\end{array}$ & 163 & $45.0 \%$ & 157 & 4 & 2 \\
\hline Study visits & 42 & $11.6 \%$ & 8 & 15 & 19 \\
\hline Contests & 75 & $20.7 \%$ & 71 & 4 & 0 \\
\hline Stalls and fairs & 39 & $10.8 \%$ & 14 & 21 & 4 \\
\hline Festivals & 43 & $11.9 \%$ & 40 & 2 & 1 \\
\hline
\end{tabular}

Source: own elaboration based on National Rural Network data.

In Podlaskie Voivodeship NRN organised mostly informational meetings, seminars, workshops and conferences, as well as contests and festivals (fig. 1). In other regions of Poland mostly stalls and fairs, as well as study visits were organised. In other countries the activity of NRN was focused on the realisation of study visits (acknowledging with good practices abroad). In other voivodeships of Poland and abroad Podlaskie Regional Secretary of NRN organised very few informational meetings etc., contests and festivals.

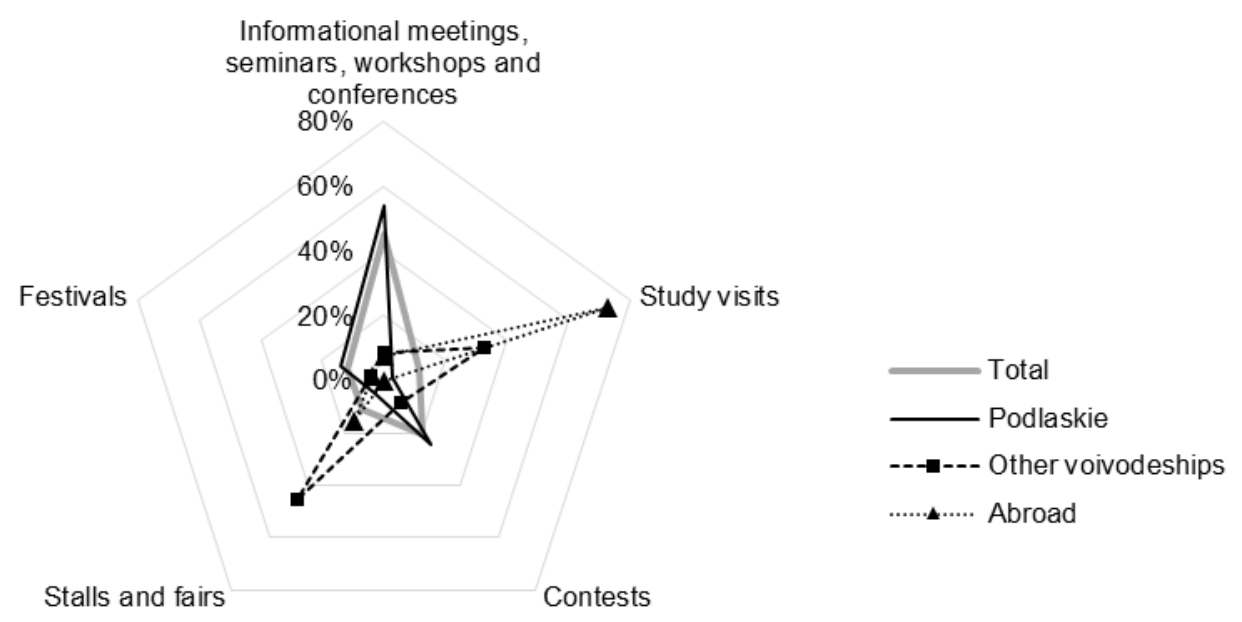

Figure 1. Types of events organised by Podlaskie Regional Secretary of NRN in 2010-2017 by location

Maps on Fig. 2 present the distribution of activities organised by Podlaskie Regional Secretary of NRN in poviats within Podlaskie voivodeship, in other voivodeships of Poland and in other countries. The distinction between five types of NRN events is also presented on the maps, and the map of Podlaskie Voivodeship includes the density of projects per thousand inhabitants.

In Podlaskie, the highest number of NRN events was organised in Białystok Poviat (126), which covers the suburban areas of Białystok, the capital of voivodeship. Wysokie Mazowieckie Powiat located south-west from Białystok was on the second place (54 events), followed by Sokółka and Siemiatycze Poviats. Out of fourteen land poviats of Podlskie voivodeships, in two (Grajewo and Zambrów Poviats) there were no NRN events organised between 2010 and 2017. Outside of Podlaskie voivodeship, the highest number of events was organised in Mazowieckie Voivodeship where Warsaw is located (10 events), and in Germany (9 events). 

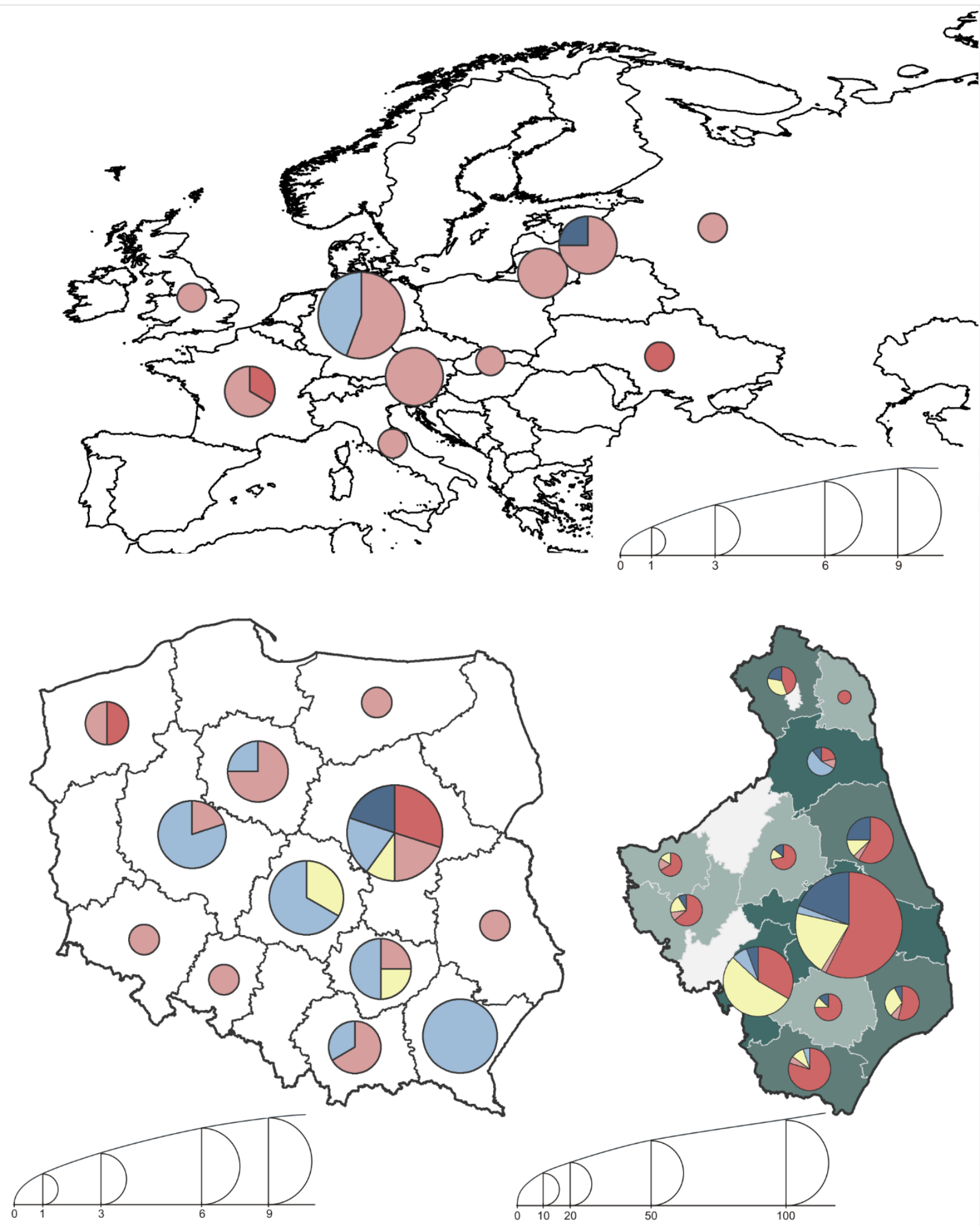

NRN events by types Informational meetings, seminars, workshops, conferences Study visits

Contests
NRN events per 1000 population

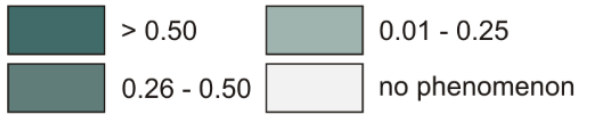

Figure 2. Distribution and structure of Podlaskie NRN activities in 2010-2017 in Podlaskie Voivodeship (bottom rights), other voivodeships of Poland (bottom left) and other countries of Europe (top) 
Informational meetings, seminars, workshops and conferences were mainly organised in Białystok Poviat. Until 2015 Wysokie Mazowieckie, Siemiatycze and Sokółka poviats were also most frequented by these events. In 2017 Kolno and Łomża poviats obtained the first place in the number of such events. Study visits were mostly organised in other voivodeships and countries. Germany was most frequented by Podlaskie NRN trips, four times in the analysed period, followed by Austria, Lithuania and Latvia. Among Polish voivodeships, Kujawsko-Pomorskie was most often visited. During few first years of the analysis, international visits were more often than domestic ones, yet since 2014 domestic visits predominate. Over two thirds of all contests organised by Podlaskie NRN took place in two poviats: Wysokie Mazowieckie Poviat (29) and Białystok Poviat (25). The remaining part was distributed between other poviats of the region, some of them also took place outside of Podlasie. Most of stalls and fairs organised by Podlaskie NRN took place in other regions of Poland, most often in Podkarpackie, Łódzkie and Wielkopolskie voivodeships. There were a bit less fairs organised inside Podlaskie region, and Augustów Poviat as well as Wysokie Mazowieckie Poviat hosted the highest number of them. All four such events organised by NRN abroad were located in Germany. Over half of festivals organised by NRN were located in Białystok Poviat. The remaining part was mostly hosted by other poviats in Podlaskie Voivodeship, mostly Sokółka Poviat. NRN organised only three festivals outside of the region, two in Mazowieckie Voivodeship and one in Latvia.

The frequency of events organised by the Podlaskie Regional Secretary of NRN changed over time (Fig. 3). It increased since 2010 reaching the top value of 86 events in 2013, later decreased and since 2015 is stable on low level of about ten events per year. Informational meetings, seminars, workshops and conferences were most numerous during first years of the analysis, and dropped since 2015. Over one third of all contests were organised in a single year 2013. The number of stands and fairs organised has been decreasing since record year 2012. Festivals were most numerously organised in 2013, and in 2016 a secondary increase in their number occurred.

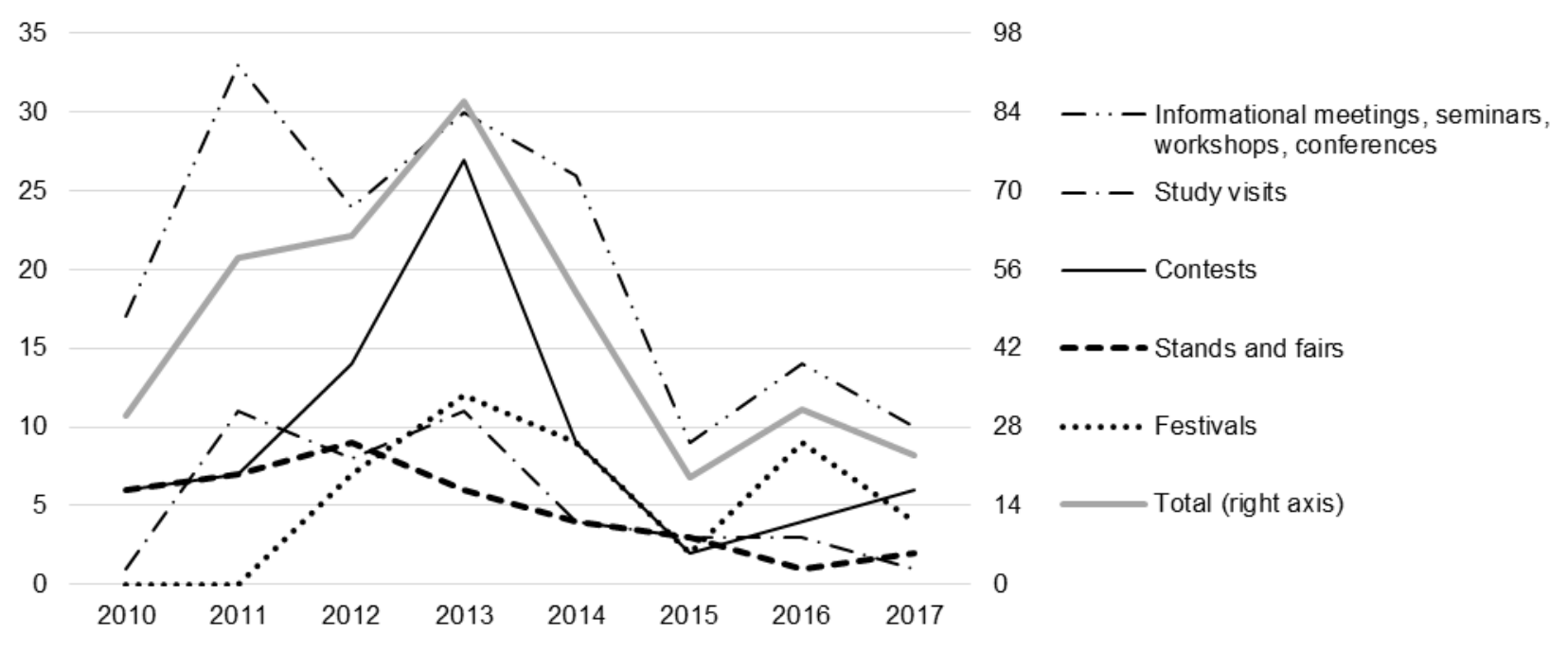

Figure 2. Change of number of Podlaskie NRN activities 2010-2017

\section{CORRELATIONS BETWEEN NUMBER OF NRN ACTIVITIES AND SOCIO-ECONOMIC INDICATORS}

In order to examine the effects of the activity of NRN on local development, several socio-economic indicators were compared with the number of NRN activities in poviats of Podlaskie Voiodeship. The number of NRN activities of all kinds were used as independent variable, while the change of values of socio-economic indicators between 2009 and 2016 were considered dependent variables, and Pearson correlation coefficients between the two were calculated. The socio-economic indicators taken into account included demographic characteristic (population), one referring to entrepreneurship (number of economic activities), two regarding employment (number of employed persons and rate of unemployment) and one describing (average monthly wages). Units of reference were all fourteen land poviats of Podlaskie Voivodeship.

Table 2 presents that Podlaskie voivodeship as a whole experienced slight decline in population, and an improvement in all measurements of economic situation during the period in the analysis: there were increases in the numbers of economic activities and total employment, the unemployment rate decreased by a quarter, and average salaries went up by almost a third. These changes did not however occur at the same pace in all parts of the voivodeship. Some poviats experienced decrease of the number of enterprises (Augustów and Zambrów Poviats), or increase of unemployment (Siemiatycze Poviat).

The analysis was performed to verify if the differences in pace and direction of economic development was correlated with the number of NRN activities, which could lead to a conclusion about the beneficial impact of NRN on local development. The activity of NRN proved to be positively correlated with change of population, number of economic activities and employed persons. All these correlations were statistically significant. Yet, the number of NRN activities is not correlated to the change of unemployment and average salary. The statistical correlation does not prove causal relation 
between NRN activity and development. This relation may also have opposite direction (more dynamic poviats attract NRN activates) or may be a result of a confounding variable, in this situation e.g. the proximity to Białystok city.

Table 2. Changes of the values of selected indicators of socio-economic development between 2009 and 2016 and its correlation with the number of NRN activities in poviats

\begin{tabular}{|l|r|r|r|r|r|}
\hline \multicolumn{1}{|c|}{ Indicator } & $\begin{array}{c}\text { Value for } \\
\text { Podlaskie in } \\
2009\end{array}$ & $\begin{array}{c}\text { Change } \\
2009-2016\end{array}$ & $\begin{array}{c}\text { Rate of } \\
\text { change } \\
2009-2016\end{array}$ & $\begin{array}{c}\text { Coefficient of correlation } \\
\text { with number of NRN } \\
\text { activities }\end{array}$ & $\begin{array}{c}\text { Two-tailed } \\
\text { significance of } \\
\text { correlation }\end{array}$ \\
\hline Population & 1189731 & -3106 & $-2.6 \%$ & 0.556 & $<0.05$ \\
\hline Number of economic activities & 89578 & +10378 & $+11.6 \%$ & 0.769 & $<0.01$ \\
\hline Number of employed persons & 207201 & +13541 & $+6.5 \%$ & -0.704 & $<0.01$ \\
\hline Rate of unemployment & $12.8 \%$ & $-2.5 \%$ & $-19.5 \%$ & -0.157 & - \\
\hline Average monthly wages (PLN) & 2884.68 & +882.52 & $+30.6 \%$ & -0.150 & \\
\hline
\end{tabular}

Source: own elaboration based on Local Data Bank, 2017.

\section{EXAMPLES OF THE IMPACT OF NRN EVENTS}

In this section we will present three examples of concrete events organised by Podlaskie Regional Secretary of NRN and describe its contribution to socio-economic development of the region.

International Practical-Academic Conference "Tourism, recreation and traditions in rural areas" was held in Ziołowy Zakątek in Koryciny on 20-21 July 2014. The conference was organized by Podlaskie NRN in cooperation with the Higher School of Physical Education and Tourism in Bialystok. Minister of Agriculture and Rural Development was the patron of the conference. The Regional Secretary of NRN financed the conference. The aims of the conference were: to exchange experiences and practices of researchers and industry professionals involved in tourism and recreation in rural areas; to present cultural values and traditions of the Podlasie region; to carry out workshops and fieldworks titled "Cultivation of herbs, processing, display of oil stamping, the brand of organic farming and its products"; and to exchange international experience. There were 70 participants from five countries: Poland, Belarus, Lebanon, Russia, and Ukraine. The speakers represented 14 Polish universities, seven foreign academic institutions, six industry institutions and six other related institutions. The conference was divided into four sections, during which 34 presentations were delivered. A survey showed that both this conference, and three other academic and practical conferences funded by NRN were highly evaluated in terms of content and organization (Kozłowska and Ryszkowski, 2015a). Among the results of this conference there were two inter-university agreements, four employment contracts, including three for academics from Belarus, four academic internships and publication of an academic monograph. Also the participants could visit the largest botanical garden in Poland, learn about the principles of herbs cultivation, their processing, ecological products and the way of building a brand of an organic farm (Kozłowska and Ryszkowski, 2015b).

Festival "Flavors of Podlasie" in open-air museum (with the staging of a Roma wedding) took place on 6 July 2014 in the Rural Museum in Białystok. The festival had many purposes and included various events taking place in the area of 27 hectares of open-air museum. Among the objectives there were: the promotion of Podlasie culture including its culinary traditions with demonstrations of organic food production, oil stamping and a unique forest distillery; a presentation of the Roma life style and the staging of a Roma wedding; performances of regional bands. Festival was preceded by a promotion campaign in the form of posters in Białystok region and advertisements in local media (Pikutin, 2015). The main innovation of the festival and a magnet attracting tourists and residents of nearby towns was the presentation of Roma life in Podlasie. The festival was visited by more than 20 thousand people. Until 2014 this was the largest event of this kind organized in the open air museum (interview with A. Gawel conducted on 5 March 2015). The Regional Secretary of the National Rural Network of Podlaskie Voivodship financed some of the projects implemented during the festival, including the staging of the Roma wedding. As a result of the project, the inhabitants of Podlasie region were introduced to the life of the Roma, which contributed to eradication of the stereotypes connected with their lives. Also, the participants learned the ways of preparing various traditional and ecological meals of the Podlasie region.

Study visit "Subsidiary use of the forest with special attention given to the herbal base on the example of the flora of Buryatia", took place on 03-10.09.2012. The trip was financed by the European Agricultural Fund for Rural Development. The purpose of the trip was to familiarize the participants with the use of the forest and to establish international cooperation with Irkutsk State University of Agriculture and other institutions, and also to learn about the role of herbs in local medicine and other uses. The participants of the trip were employees of the State Forests, Regional Directorate for Environmental Protection, and representatives of herbal industry from Ziołowy Zakątek in Korycin (Grodzisk commune). The result of the trip was the introduction of local cultivation of herbs, which to date had been largely imported to Poland. Cultivation of herbal plants, other plants, and pharmaceutical species was introduced in the Podlasie region, especially to Ziołowy Zakątek in Korycin (botanical garden). The newly introduced species of herbs included: leafy species of garlic, gentian, thyme, epilobium, speedwell, eyebright, garden angelica, berberis, artemisia, agrimony, hypericum, and others (Sprawozdanie merytoryczne..., 2012). Siberian varieties of these plants are attractive due to the size of plants and fruits, their aroma and the pace of growth. A few years after the introduction of plants into the botanical garden in Korycin, the arrivals of tourists and scientists have increased significantly. Growing atypical plants attracts crowds of tourists both from Poland and abroad. Nowadays, Ziołowy Zakątek, which benefited most from the study trip, has become a destination for tourism trips and research in the field of agriculture. 


\section{SUMMARY}

Networking plays a significant role among the instruments of the European Union rural policy. It includes the creation of regional public-private partnerships, inter-territorial and transnational cooperation, and the functioning of national rural networks, integrated within the European Network for Rural Development. The activities of these institutions are considered to be engines of the development of rural areas. National rural networks are present in each of EU member states. They involve various stakeholder groups to promote knowledge, cooperation and exchange of experience. Their main task is to increase the effectiveness of rural development programs and improve the implementation of EU policies.

The significance of NRNs in the development of rural areas in Podlaskie Voivodeship manifests itself in many aspects. Podlasie NRN Secretary uses such tools as internet portal, seminars and conferences, fairs, or study visits to initiate various forms of cooperation between partners. It works on current and potential problems of rural development and facilitate exchange and transfer of experiences between rural areas both in and outside of the region. Podlasie NRN cooperates with local action groups in various voivodeships of Poland, and also in other EU member states, mainly in Germany, Austria, Latvia, France and Lithuania.

To date, research on the effectiveness of NRN activities has been sparse. The results of our analysis confirm that they are an important instrument supporting the socio-economic development of rural areas. The comparison of NRN activity and the dynamics of socio-economic development in administrative units of the region did not provide clear prove to judge on the causal effect of NRN activity on local development noticeable on high level of aggregation. However, the cases of concrete events organised by NRN described above had a tangible impact on the economic activity, employment, knowledge and regional awareness of the residents of the region. The authors see the need to extend research into the issue. It would be valuable to conduct more in-depth case studies, comparative research in various locations, as well as longitudinal studies to understand socio-economic transformations facilitated by the activities of rural networks on local level.

\section{REFERENCES}

1. Co to jest KSOW?. 2009. Ministerstwo Rolnictwa i Rozwoju Wsi, Warszawa. [In Polish]

2. Council Regulation (EC) No 1698/2005 of 20 September 2005 on support for rural development by the European Agricultural Fund for Rural Development (EAFRD).

3. Czapiewska, G. 2015. Rola i znaczenie sieci obszarów wiejskich w rozwoju pomorskich wsi. Stupskie Prace Geograficzne, Vol. 12, pp. 5-19. [In Polish]

4. Drygas, M. 2010. Krajowa Sieć Obszarów Wiejskich Dylematy i pożądane kierunki rozwoju. Na przykładzie doświadczeń wybranych krajów realizujących tego typu przedsięwzięcia. IRWiR PAN, Warszawa. [In Polish]

5. Kozłowska, D., Ryszkowski, W. 2015a. Kategoria zadowolenia jako kryterium oceny konferencji (KSOW, PO Ryby 2007-2013). In: D. Kozłowska, L. Kozłowski (Ed.), Innowacyjne działania i gospodarstwa na obszarach wiejskich. PTG OT, Toruń, pp. 266278. [In Polish]

6. Kozłowska, D., Ryszkowski, W. 2015b. Organizacja konferencji naukowo-praktycznych jako element polityki rozwoju obszarów wiejskich. In: D. Kozłowska, L. Kozłowski (Ed.), Innowacyjne działania i gospodarstwa na obszarach wiejskich. PTG OT, Toruń, pp. 94-125. [In Polish]

7. Król, M. 2010. Funkcjonowanie Krajowej Sieci Obszarów Wiejskich ze szczególnym uwzględnieniem struktur organizacyjnych, jak również dostępności informacji w ramach KSOW. KSOW, Warszawa.

8. Kutkowska, B., Pilawka, T. 2014. Rola krajowej sieci obszarów wiejskich (KSOW) w budowaniu kapitału społecznego wsi. Prace Naukowe Uniwersytetu Ekonomicznego we Wroctawiu, No. 341, pp. 104-119. [In Polish]

9. Local Data Bank. 2017. Central Statistical Office. Available at https://bdl.stat.gov.pl/BDL/start (Accessed 13/11/2017)

10. Marquardt, D., Hubbard, C. 2014. National Rural networks - Lessons for Policy formation and implementation within the CAP post 2013. In: D. M. Voicilas, M. Tudor (Eds.), Rural transformations under Common Agricultural Policy 2007-2013 and future development, Edition 1. ERDN, Warsaw-Bucharest, 137-156.

11. Miś, T. 2015. Rola kapitału społecznego w zrównoważonym rozwoju obszarów wiejskich. Nierówności Społeczne a Wzrost Gospodarczy, Vol. 42 (2/2015), pp. 282-295. [In Polish]

12. Ocena funkcjonowania Krajowej Sieci Obszarów Wiejskich w Polsce na tle wybranych państw członkowskich Unii Europejskiej. 2011. Ministerstwo Rolnictwa i Rozwoju Wsi, Warszawa.

13. Onofrei, L., Csosz, I., Chis, D., Banc, I. 2009. The rural development network within the European Union. Lucrări Ştiinţifice, Seria I 11, pp. 493-500.

14. Peters, R., Gregory, M. 2014. Networking, Small Farms and EU Rural Development Policy. EuroChoices, Vol. 13, No. 1, pp. 36-39.

15. Pikutin, E. 2015. Edukacyjne wartości festynów i imprez rekreacyjnych w Skansenie Białostockiego Muzeum Wsi. Unpublished master thesis. WSWFiT, Białystok. [In Polish]

16. Sprawozdanie merytoryczne $\mathrm{z}$ realizacji wyjazdu studyjnego w zakresie Ubocznego użytkowania lasu ze szczególnym uwzględnieniem bazy zielarskiej na przykładzie flory Buriacji. 2012. Ministerstwo Rolnictwa i Rozwoju Wsi. Available at http://podlaskie.ksow.pl/fileadmin/user_upload/podlaskie/pliki/publikacje_2012/SPRAWOZDANIE_SYBERIA_2012.pdf (Accessed 13/11/2017) [In Polish] 